\title{
DEVELOPMENT AND VALIDATION OF A REVERSE PHASE-HIGH PERFORMANCE LIQUID CHROMATOGRAPHY-ULTRAVIOLET METHOD FOR SIMULTANEOUS DETECTION OF CAFFEINE AND PHENOLPHTHALEIN IN WEIGHT REDUCING SUPPLEMENTS
}

\section{(Pembangunan dan Pengesahsahihan Kaedah Fasa Terbalik-Kromatografi Cecair Prestasi Tinggi Ultraungu bagi Pengesanan Kafein dan Fenolftalein Dalam Suplemen Pengurangan Berat Badan)}

\author{
Elham Mohammadi Nasr and Lai Chun Wong* \\ Department of Pharmaceutical Chemistry, School of Pharmacy, \\ International Medical University, 57000 Kuala Lumpur, Malaysia \\ *Corresponding author: laichunwong@imu.edu.my
}

Received: 13 May 2016; Accepted: 12 April 2017

\begin{abstract}
A reversed-phase high performance liquid chromatography analytical method with variable wavelength detection was developed for the simultaneous detection of caffeine and phenolphthalein in weight reducing supplements. Chromatographic separation was achieved with a C18 reversed-phase column using a gradient elution of methanol and an ammonium acetate buffer (pH 5; 25 $\mathrm{mM}$ ), with the detector wavelength set at $254 \mathrm{~nm}$. The method was validated according to The International Conference on Harmonisation of Technical Requirements for Registration of Pharmaceuticals for Human Use guidelines. The method was proven to be linear over a concentration of $10-100 \mu \mathrm{g} / \mathrm{mL}$ for both caffeine and phenolphthalein, with mean correlation coefficients of 1.000 and 0.999 , respectively. The limit of detection for caffeine and phenolphthalein was $0.77 \mu \mathrm{g} / \mathrm{mL}$ and 0.47 $\mu \mathrm{g} / \mathrm{mL}$ respectively, while the limit of quantification for caffeine and phenolphthalein was $2.35 \mu \mathrm{g} / \mathrm{mL}$ and $1.44 \mu \mathrm{g} / \mathrm{mL}$, resspectively. The percentage relative standard deviation for both intra and inter-day precision was less than $2 \%$. The mean recovery values were calculated as $105.84 \%$ and $113.58 \%$ for caffeine and phenolphthalein. In addition, the method was proven to be robust when deliberate changes in flow rate, buffer $\mathrm{pH}$ and organic mobile phase composition were tested.
\end{abstract}

Keywords: caffeine, phenolphthalein, high performance liquid chromatography, validation, weight reducing supplement

\begin{abstract}
Abstrak
Satu kaedah analitikal kromatografi cecair prestasi tinggi (KCPT) fasa terbalik dengan pengesanan pada pelbagai panjang gelombang telah dibangunkan untuk pengesahan kafein dan fenolftalein dalam suplemen pengurangan berat badan. Pemisahan kromatografik dicapai dengan turus fasa terbalik C18 menggunakan kecerunan elusi metanol dan penampan ammonium asetat (pH 5; $25 \mathrm{mM}$ ), pada panjang gelombong $\lambda=254 \mathrm{~nm}$. Kaedah ini telah ditentusahkan mengikut garis panduan harmonisasi persidangan antarabangsa keperluan teknikal untuk pendaftaran famaseutikal bagi pengunaan manusia. Kaedah ini dibuktikan linear dalam julat kepekatan larutan piawai kafein dan fenolftalein di antara $10-100 \mu \mathrm{g} / \mathrm{mL}$ dengan nilai pekali korelasi $\left(\mathrm{R}^{2}\right)$ 1.000 dan 0.999 untuk masing - masing bagi kafein dan fenolftalein. Had pengesanan bagi kafein dan fenolftalein masingmasing ialah $0.77 \mu \mathrm{g} / \mathrm{mL}$ and $0.47 \mu \mathrm{g} / \mathrm{mL}$. Keputusan had kuantifikasi bagi kafein dan fenolftalein masing-masing ialah 2.35 $\mu \mathrm{g} / \mathrm{mL}$ and $1.44 \mu \mathrm{g} / \mathrm{mL}$. Peratus relatif sisihan piawai bagi ketepatan intra dan antara hari yang diukur ialah kurang dari nilai $2 \%$. Nilai min pemulihan semula yang dikira bagi kafein dan fenolftalein masing-masing ialah 105.84 dan $113.58 \%$. Kaedah ini juga dibuktikan teguh apabila perubahan dalam kadar aliran, $\mathrm{pH}$ panampan dan komposisi fasa bergerak diuji.
\end{abstract}




\section{Wong \& Nasr: DEVELOPMENT AND VALIDATION OF A REVERSE PHASE-HIGH PERFORMANCE LIQUID CHROMATOGRAPHY-ULTRAVIOLET METHOD FOR SIMULTANEOUS DETECTION OF CAFFEINE AND PHENOLPHTHALEIN IN WEIGHT REDUCING SUPPLEMENTS}

Kata kunci: kafein, fenolftalein, kromatografi cecair prestasi tinggi, pengesahsahihan, suplemen pengurangan berat badan

\section{Introduction}

Obesity is a worldwide health epidemic. It is reported that among adults aged 18 and above, $11 \%$ of men and $15 \%$ of women were obese in 2014 [1]. Because of the health risks associated from being overweight, and also pressure from society to have a slim and attractive body, weight reducing supplements are popular worldwide among both men and women. The majority of these weight reducing supplements are marketed as being derived from phytotherapeutic formulations and are advertised as being natural and safe. Unfortunately this is not the case in reality, as there have been many reports worldwide of weight reducing supplements being adulterated with undeclared prescription pharmaceuticals and banned substances to enhance their efficiency [2-11].

In the US, the Food and Drug Administration (FDA) has detected the presence of adulterants such as sibutramine, fenproporex, fluoxetine, bumetanide, furosemide, phenytoin, rimonabant, cetilistat and phenolphthalein in various weigh reducing products sold over the counter (OTC) and online [12]. We are interested in developing a simple and fast HPLC method to quantify caffeine and phenolphthalein, as these compounds are popular choices as adulterants due to their relatively cheap price and easy accessibility. Phenolphthalein, a synthetic compound, was a stimulant laxative used for the treatment of constipation and for bowel evacuation until 1999, when the FDA reclassified the drug as 'not generally safe and effective' after studies indicated that it presented a potential carcinogenic risk [13]. Since then, the United Kingdom has changed the status of phenolphthalein from OTC to prescription agent, while European countries such as Italy and France have suspended the use of it in prescription and OTC pharmaceutical preparations $[14,15]$.

Caffeine is a natural product found in the leaves, seeds, and fruits of more than 60 plants [16]. As a stimulant, caffeine was reported to be one of the most used drugs for slimming purposes [3]. Consuming caffeine increases energy expenditure, making the individual more alert and hence more active, leading to weight loss [17]. Caffeine has also been proposed to counteract the decrease in metabolic rates, and may also act as an appetite suppressant. Although complications due to caffeine toxicity are rare, excessive consumption of caffeine can lead to health problems such as sleep disruption, headache, nausea, anxiety, and even caffeine-induced cardiac arrhythmia $[18,19]$. The chemical structures of caffeine and phenolphthalein are shown in Figure 1 below.

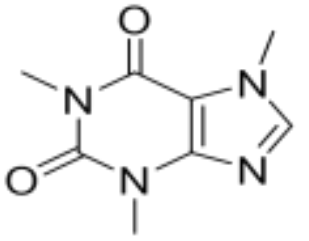

A. Caffeine

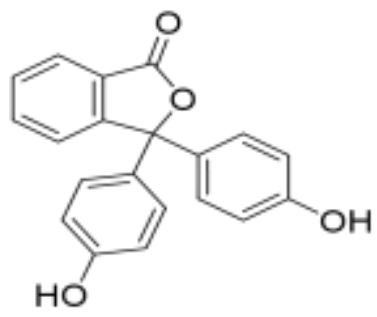

B. Phenolphthalein

Figure 1. Chemical structures of the adulterants of interest (a) Caffeine (1,3,7-trimethyl-3,7-dihydro-1H-purine2,6-dione) and (b) Phenolphthalein (3,3-Bis(4-hydroxyphenyl)-2-benzofuran-1(3H)-one)

In this paper, the development and validation of a reversed-phase high performance liquid chromatography-ultra violet (RP-HPLC-UV) analytical method to detect caffeine and phenolphthalein in weight reducing supplements was investigated. The developed method was validated according to The International Conference on Harmonisation of Technical Requirements for Registration of Pharmaceuticals for Human Use (ICH) guidelines [20]. Among the existing analytical methods reported in the literature to detect caffeine and phenolphthalein simultaneously are ultra-high performance liquid chromatography (UHPLC) and liquid chromatography-mass 
spectroscopy (LC-MS) [9, 21]. Recently, an article was published reporting a HPLC-UV method for quantitative determination of six adulterant drugs, including caffeine and phenolphthalein, in slimming supplements [22]. However, the published method uses different HPLC parameters from our study. The method which we have developed can be applied to analytical laboratories in developing countries which are only equipped with HPLC-UV instrumentation to screen and quantify for caffeine and phenolphthalein in weight reducing supplements.

\section{Chemicals and reagents}

\section{Materials and Methods}

Caffeine ( $\geq 99.0 \%)$ and phenolphthalein (ACS reagent), used as standards, were purchased from Sigma Aldrich and Merck, respectively. HPLC-grade methanol and ammonium acetate (>99\%) was obtained from Fischer Scientific. The mobile phase was filtered through a $0.45 \mu \mathrm{m}$ nylon membrane filter and ultrasonically degassed before use. Other reagents, including glacial acetic acid, were of analytical grade. Ultrapure water was prepared using an atrium $^{\circledR} 611$ Ultrapure Water System (Sartorius, Germany).

\section{Instrumentation and chromatographic system}

Method development and validation was performed on a 1200 series HPLC (Agilent Technologies, US), interfaced with a binary pump (G1312A, Agilent Technologies, US), degasser (G1379B, Agilent Technologies, US), variable wavelength detector (VWD) (Agilent Technologies, US) and manual injector (G1328B, Agilent Technologies, US). The HPLC was interfaced to a Hewlett-Packard L1908 computer equipped with ChemStation System (version 2008) software.

The chromatography method was developed using a C18 Hypersil GOLD column (150 mm x $4.6 \mathrm{~mm}$ internal diameter, $5 \mu \mathrm{m}$ particle size) at room temperature. The mobile phase was composed of (A) an ammonium acetate buffer $25 \mathrm{mM}$ solution adjusted to $\mathrm{pH} 5$ with glacial acetic acid and (B) methanol with a gradient elution programme, as shown in Table 1 . The mobile phase was delivered at a flow rate of $1.1 \mathrm{~mL} / \mathrm{min}$. The injection loop volume was $20 \mu \mathrm{l}$. The detection wavelength was set at $254 \mathrm{~nm}$.

Table 1. Gradient elution profile used in HPLC system

\begin{tabular}{lccccc}
\hline Time (min) & $\mathbf{0}$ & $\mathbf{1}$ & $\mathbf{3}$ & $\mathbf{5}$ & $\mathbf{1 0}$ \\
\hline A (\%) & 90 & 90 & 60 & 45 & 45 \\
B (\%) & 10 & 10 & 40 & 55 & 55 \\
\hline A = ammonium acetate buffer $(\mathrm{pH} 5 ; 25 \mathrm{mM}) ; \mathrm{B}=$ methanol
\end{tabular}

\section{Preparation of stock standard solution}

Stock standard solutions of $1 \mathrm{mg} / \mathrm{mL}$ caffeine and phenolphthalein were prepared separately in HPLC grade methanol. The resulting stock solutions were sonicated and filtered using a $0.2 \mu \mathrm{m}$ nylon syringe filter.

\section{Preparation of mixed standard and mixed working solution}

Mixed standard solution in concentration $100 \mu \mathrm{g} / \mathrm{mL}$ was prepared from the stock standard solutions. Using this tertiary solution, mixed working solutions of $10,20,40,60$ and $80 \mu \mathrm{g} / \mathrm{mL}$ were prepared by diluting with the appropriate amount of methanol. All solutions were prepared in HPLC grade methanol, stored in a refrigerator $\left(4^{\circ} \mathrm{C}\right)$ and brought to room temperature before use.

\section{Preparation of blank sample}

The blank sample for validation of specificity was prepared according to methods modified from the literature $[5,10]$. A herbal weight reducing supplement purchased from a local pharmacy was considered as a blank sample. The capsule was opened, and $0.1 \mathrm{~g}$ of powder was weighed. The powder was then extracted with $25 \mathrm{~mL}$ of HPLC grade methanol by sonication for 10 minutes. The mixture was then centrifuged at $10000 \mathrm{rpm}$ for five minutes, and 


\section{Wong \& Nasr: DEVELOPMENT AND VALIDATION OF A REVERSE PHASE-HIGH PERFORMANCE LIQUID CHROMATOGRAPHY-ULTRAVIOLET METHOD FOR SIMULTANEOUS DETECTION OF CAFFEINE AND PHENOLPHTHALEIN IN WEIGHT REDUCING SUPPLEMENTS}

the supernatant was then collected and filtered through a $0.2 \mu \mathrm{m}$ nylon syringe filter. The blank sample was stored at $4{ }^{\circ} \mathrm{C}$ in the refrigerator and brought to room temperature before injection into the HPLC.

\section{System suitability tests}

System suitability tests were carried out before performing validation parameters. The following system suitability tests were performed: peak symmetry, number of theoretical plates, resolution and capacity factor.

\section{Method validation}

The method validation was performed according to ICH guidelines for the following parameters: specificity, linearity, limit of detection (LOD), limit of quantification (LOQ), accuracy, precision, and robustness. Stability of a mixed working solution at a $50 \mu \mathrm{g} / \mathrm{mL}$ concentration was also investigated.

\section{Specificity}

Specificity is defined as the ability to assess unequivocally the analytes in the presence of components which may be expected to be present. Specificity was determined by injecting blank samples into the HPLC system to test for interference of a complex matrix of the blank samples with caffeine and phenolphthalein peaks. Blank samples used were OTC weight reducing supplements.

\section{Linearity of the calibration curve}

The linearity of the calibration curves were constructed by analysing mixed working solutions of caffeine and phenolphthalein. Six concentrations of mixed working solutions containing them ranging from $10 \mu \mathrm{g} / \mathrm{mL}$ to 100 $\mu \mathrm{g} / \mathrm{mL}$ were prepared. The linearity was obtained by the injection of the mixed standard working solutions at each concentration in triplicates $(n=3)$, and the results were expressed as the mean of the triplicates.

\section{Limit of detection and limit of quantification}

The LOD is defined as the lowest analyte concentration of a sample that can be detected by the analyst, while LOQ is the lowest analyte concentration which can be quantitatively detected with accuracy and acceptable precision. The LOD is expressed as $3.3 \delta / \mathrm{S}$, and LOQ is expressed as $10 \delta / \mathrm{S}$, where S refers to the slope of the calibration curve and $\delta$ refers to the standard deviation of the response. The value of $\delta$ was determined from the residual standard deviation of the calibration curve.

\section{Accuracy}

The accuracy of the method, expressed as percentage recovery (\% recovery), was established via spiking studies. The $\%$ recovery values were evaluated by spiking blank samples with low, medium and high levels of caffeine and phenolphthalein standards. The concentrations of caffeine standard spiked into the samples were 11, 22 and 33 $\mu \mathrm{g} / \mathrm{mL}$, while the concentrations of phenolphthalein standard spiked were $10.44,20.88$ and $31.32 \mu \mathrm{g} / \mathrm{mL}$. Each standards of the same concentration was injected into the HPLC in triplicates $(n=3)$ and the results are expressed as the mean of the triplicates. The \% recovery values were established by calculating the ratio of the experimentally determined concentration of each analytes spiked into the blank samples to its theoretical amount (equation 1):

$$
\% \text { Recovery }=\frac{(\text { Recovered concentration of analytes })}{(\text { Theoretical concentration of analytes })} \times 100 \%
$$

\footnotetext{
Precision

Precision is the measure for the relative errors of the method and is expressed as the percentage relative standard deviation (\% RSD) for intra-day precision (repeatability) and inter-day precision (intermediate precision). To find the intra-day precision, mixed working solutions at low, medium and high concentrations were injected consecutively in the same day. Each sample of a similar concentration was injected in triplicates $(\mathrm{n}=3)$, and the results were expressed as the mean of the triplicates. To find the inter-day precision, the process to do so was repeated where injections of mixed working standard solutions at low, medium and high concentrations were performed over three consecutive days. Each sample of a similar concentration was injected in triplicates $(n=3)$, and the results were expressed as the mean of the triplicates.
} 


\section{Stability of mixed standard solution}

A mixed working solution of concentration $50 \mu \mathrm{g} / \mathrm{mL}$ was prepared fresh. The stability of this solution was checked after 24 hours under refrigerated conditions $\left(4^{\circ} \mathrm{C}\right)$.

\section{Robustness}

The robustness of the method was determined by analysing the mixed standard solution after deliberate changes in flow rate $( \pm 0.2 \mathrm{~mL} / \mathrm{min})$, buffer $\mathrm{pH}( \pm 0.2$ units) and organic content of the mobile phase $( \pm 2.0 \%)$. System suitability was applied after each of the above mentioned changes. The method is considered robust for the parameter tested if it conforms to the system suitability tests.

\section{Preparation of representative samples}

The representative samples were prepared according to similar method employed to prepare the blank sample. Five weight reducing supplements in the form of capsules and powder were purchased from the Kuala Lumpur area (products A, B, C, D and E). The filtered solution of product A was diluted by 10 times with HPLC grade methanol before injection into the HPLC to obtain concentrations within the calibration range. No dilutions were required for the other samples before injection into the HPLC. All solutions were injected in triplicate.

\section{Liquid-liquid extraction (LLE)}

To clean-up product E, $0.05 \mathrm{~g}$ of the product was weighed and dissolved in $20 \mathrm{~mL}$ sodium carbonate solution. Solids were removed by filtering, and the filtrate collected into a separating funnel. The filtrate was extracted with dichloromethane $(20 \mathrm{~mL} \times 3)$, the dichloromethane fractions pooled into a round bottom flask and the solvent removed using a rotary evaporator. The residue left in the round bottom flask was reconstituted with $10 \mathrm{~mL}$ of HPLC grade methanol and filtered through a $0.2 \mu \mathrm{m}$ nylon syringe filter prior to injection into the HPLC.

\section{Selection and optimisation of the method}

\section{Results and Discussion}

The chromatographic method was optimised during the method developing stage by trying different mobile phase compositions and flow rates. The final method was obtained using an ammonium acetate buffer $(\mathrm{pH} 5 ; 25 \mathrm{mM})$ as an aqueous mobile phase and methanol as an organic mobile phase at a flow rate of $1.1 \mathrm{~mL} / \mathrm{min}$. The buffer was used as an aqueous mobile phase to obtain good peak shape and a constant retention time, as caffeine and phenolphthalein contains $\mathrm{pH}$ sensitive functional groups [23, 24]. Additional peaks were observed when ammonium acetate buffer $\mathrm{pH} 5$ was substituted with ammonium acetate buffer $\mathrm{pH} 3.8$ and $\mathrm{pH} 5.8$ (Figures 2a and 2b). The optimum wavelength allowing for sensitive detection for both caffeine and phenolphthalein was set at $254 \mathrm{~nm}$ based on literature $[9,10,25]$.

The elution gradient begins with $10 \%$ methanol and $90 \%$ buffer. After one minute a linear gradient is started where $40 \%$ methanol composition is reached after 2 minutes from the time of gradient. A second linear gradient is then applied where methanol composition increases to $55 \%$ after 2 minutes and kept constant for 5 minutes until caffeine and phenolphthalein elutes out at 5.61 minutes and 8.78 minutes respectively. The separation achieved using the experimental conditions described are presented in Figure 2c. The following system suitability test parameters were performed: peak symmetry, number of theoretical plates, resolution and capacity factor (Table 2). All system suitability test parameters were found to be within the ICH requirements. 
Wong \& Nasr: DEVELOPMENT AND VALIDATION OF A REVERSE PHASE-HIGH PERFORMANCE LIQUID CHROMATOGRAPHY-ULTRAVIOLET METHOD FOR SIMULTANEOUS DETECTION OF CAFFEINE AND PHENOLPHTHALEIN IN WEIGHT REDUCING SUPPLEMENTS
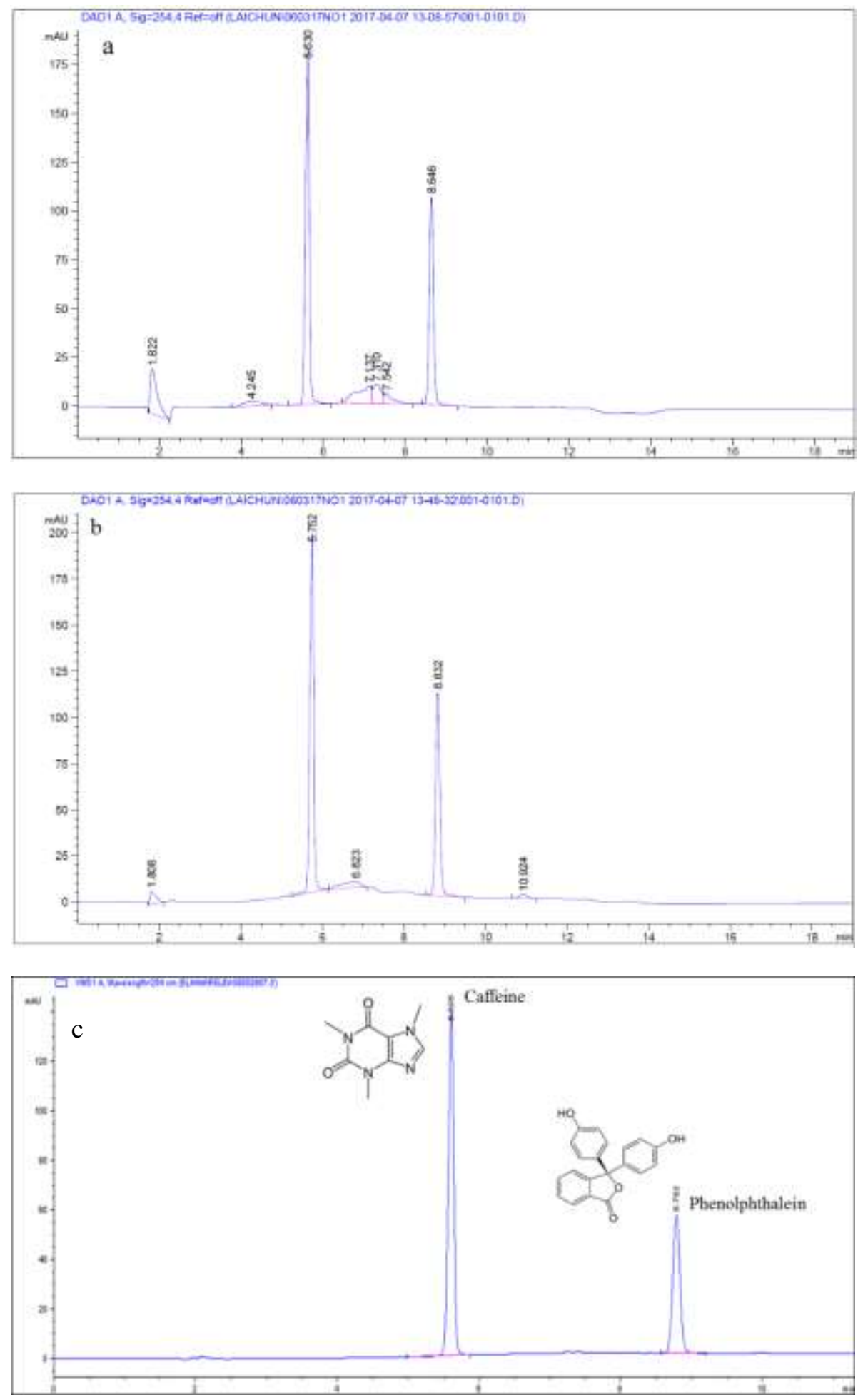

Figure 2. The HPLC chromatogram of mixed working solution $(50 \mu \mathrm{g} / \mathrm{mL})$ under chromatographic conditions of the developed method with ammonium acetate buffer at (a) $\mathrm{pH} 3.8$; (b) $\mathrm{pH} 5.8$ and (c) $\mathrm{pH} 5$ 
Table 2. System suitability test parameters

\begin{tabular}{lccc}
\hline Parameters & Caffeine & Phenolphthalein & $\begin{array}{c}\text { ICH } \\
\text { Requirement }\end{array}$ \\
\hline Numbers of theoretical plate & 43442 & 58100 & $>10000$ \\
Peak symmetry & 1.5 & 1.3 & $<2$ \\
Retention factor (min) & 2.18 & 4.04 & - \\
Precision (\%RSD, $\mathrm{n}=6)$ & 1.32 & 1.49 & $<2 \%$ \\
Resolution (R) & 26.125 & 26.125 & $>1.5$ \\
\hline
\end{tabular}

\section{Validation criteria of the HPLC method: Specificity}

Specificity was indicated by the absence of any endogenous interference at retention times close to the peaks of interest, as evaluated by chromatograms of blank samples and blank samples spiked with analytes. Retention times for caffeine and phenolphthalein in the spiked sample were 5.652 minutes and 8.987 minutes respectively. In the blank sample, no interfering peaks were found at the retention times of caffeine and phenolphthalein (Figure 3).
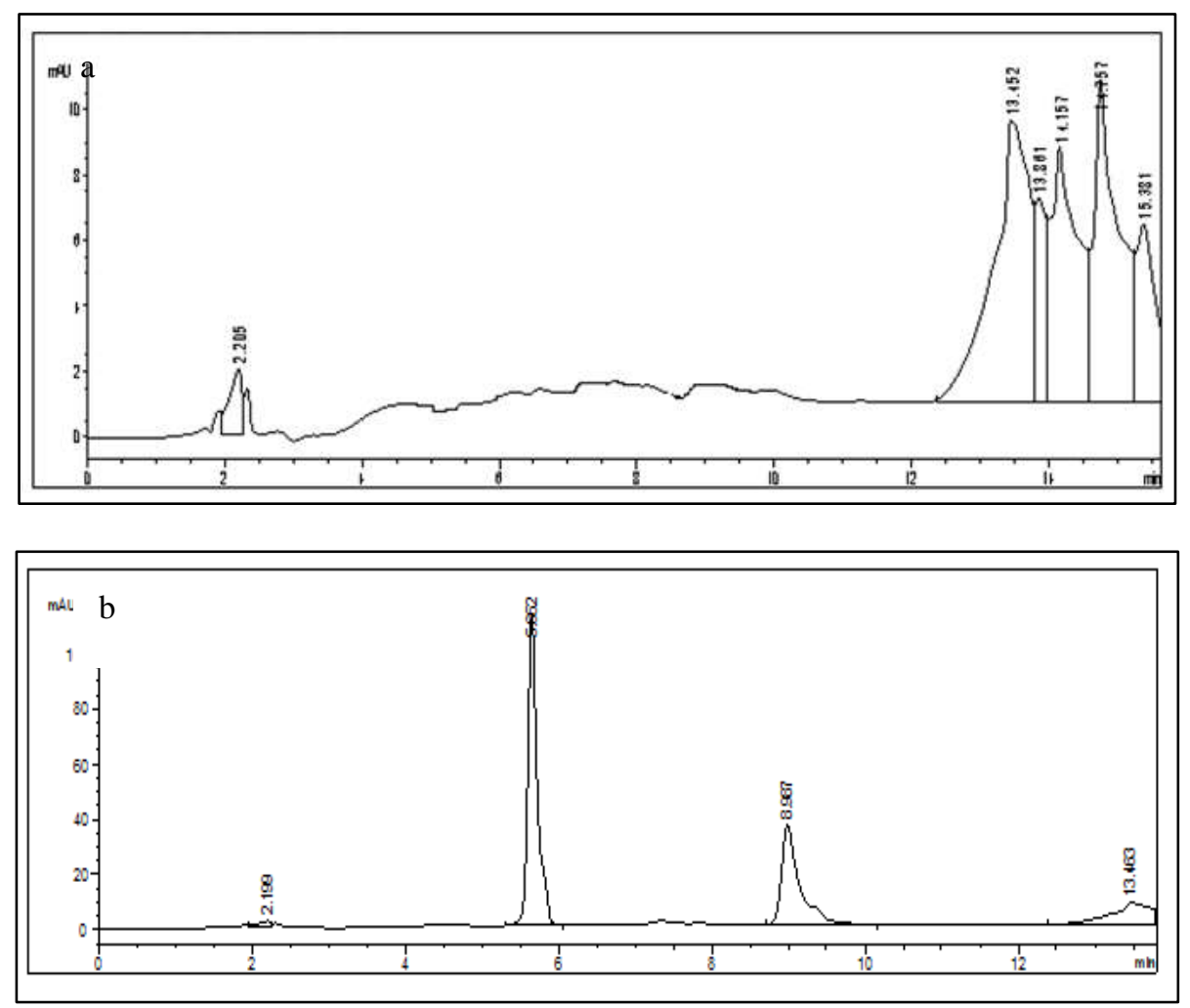

Figure 3. Representative chromatograms for (a) blank sample and (b) blank sample spiked with caffeine (50 $\mu \mathrm{g} / \mathrm{mL})$ and phenolphthalein $(50 \mu \mathrm{g} / \mathrm{mL})$ 


\section{Wong \& Nasr: DEVELOPMENT AND VALIDATION OF A REVERSE PHASE-HIGH PERFORMANCE LIQUID CHROMATOGRAPHY-ULTRAVIOLET METHOD FOR SIMULTANEOUS DETECTION OF CAFFEINE AND PHENOLPHTHALEIN IN WEIGHT REDUCING SUPPLEMENTS}

\section{Linearity}

The calibration curves for caffeine and phenolphthalein were plotted using ordinary least-square linear regression over the concentration range $10 \mu \mathrm{g} / \mathrm{mL}$ to $100 \mu \mathrm{g} / \mathrm{mL}$ (Figure 4). A linear relationship was established between the peak area and analyte concentrations over the range tested, and it was confirmed by the correlation coefficient $\left(\mathrm{R}^{2}\right)$ value where $R^{2}$ values were higher than 0.990 . The slope and intercept of the calibration curve was calculated, and the following linear equation was obtained: $y=22.751 x+66.613$ for caffeine and $y=11.352 x+5.716$ for phenolphthalein. Therefore, it can be concluded that the calibration curves for caffeine and phenolphthalein is linear within the range $10 \mu \mathrm{g} / \mathrm{mL}$ to $100 \mu \mathrm{g} / \mathrm{mL}$.

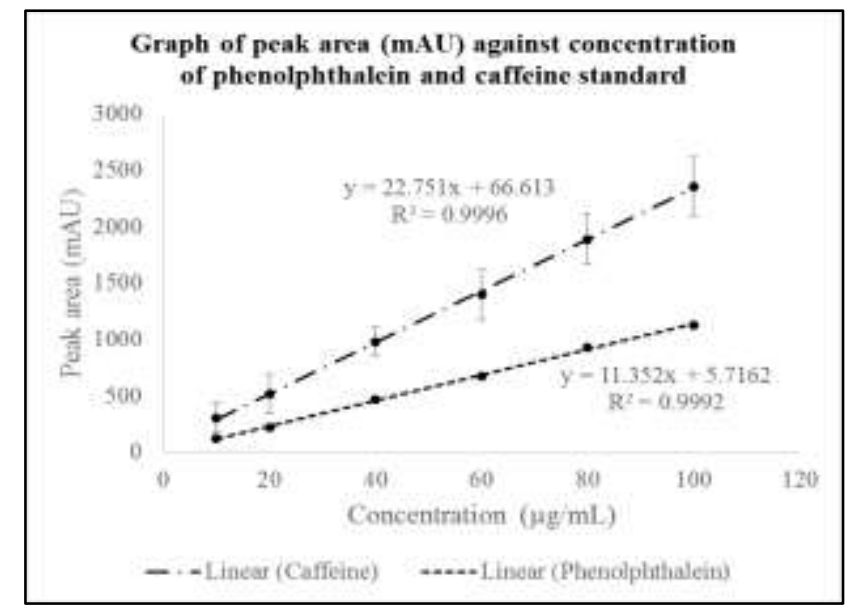

Figure 4. Calibration curve for caffeine and phenolphthalein in concentration range $10-100 \mu \mathrm{g} / \mathrm{mL}$

\section{Limit of detection and limit of quantification}

The LOD for both caffeine and phenolphthalein determined from the residual standard deviation of the regression line was found to be $0.77 \mu \mathrm{g} / \mathrm{mL}$ and $0.47 \mu \mathrm{g} / \mathrm{mL}$, respectively. The LOQ for caffeine and phenolphthalein determined from the residual standard deviation of a regression line was found to be $2.35 \mu \mathrm{g} / \mathrm{mL}$ and $1.44 \mu \mathrm{g} / \mathrm{mL}$, respectively. The LOD and LOQ values for caffeine were found to be comparable with those reported in a previous study using HPLC-UV $(0.75 \mu \mathrm{g} / \mathrm{mL}$ and $2.25 \mu \mathrm{g} / \mathrm{mL}$ respectively) [22]. However, the LOD and LOQ values for phenolphthalein obtained in this study were higher than the values reported in the previous study $(0.1 \mu \mathrm{g} / \mathrm{mL}$ and $0.3 \mu \mathrm{g} / \mathrm{mL}$, respectively) [22]. The higher LOD and LOQ values for phenolphthalein could be attributed by the different wavelength used in our study $(254 \mathrm{~nm})$ compared to the previous one $(220 \mathrm{~nm})$.

\section{Accuracy}

The percentage recovery values of caffeine and phenolphthalein at low, medium and high concentrations are summarised in Table 3. The mean percentage recovery values for caffeine and phenolphthalein in the range of concentration tested were found to $105.84 \%$ and $113.58 \%$ respectively. The method was proven to be accurate in measuring caffeine and phenolphthalein in the concentrations tested, where the measured concentration values were close to the true values.

\section{Precision}

The intra-day precisions for caffeine and phenolphthalein were found to be between $0.67-1.99 \%$ and 0.80 $1.55 \%$, respectively, while the inter-day precisions for caffeine and phenolphthalein over three consecutive days were between $0.67-1.99 \%$ and $0.80-1.79 \%$, respectively. In both cases, percentage RSD values were found well within the $2 \%$ limit. Therefore, the method is proven to be repeatable and is capable of producing consistent results regardless of whether the analysis is made in the same or on different days. The percentage RSD values for precision are summarised in Table 4. 
Table 3. Accuracy of the HPLC method expressed as percentage recovery (\% recovery), determined using spiking (three spike levels) experiment

\begin{tabular}{llccc}
\hline Spike Levels & Compound & $\begin{array}{c}\text { Spiked (Theoretical) } \\
\boldsymbol{\mu g} / \mathbf{m L}\end{array}$ & $\begin{array}{c}\text { Spiked (Found) } \\
\mathbf{\mu g} / \mathbf{m L}\end{array}$ & $\begin{array}{c}\text { \% Recovery } \\
(\mathbf{n}=\mathbf{3})\end{array}$ \\
\hline \multirow{2}{*}{ Low } & Caffeine & 11.00 & 11.49 & $104.45 \pm 3.82$ \\
& Phenolphthalein & 10.44 & 12.54 & $120.11 \pm 4.50$ \\
\hline \multirow{2}{*}{ Medium } & Caffeine & 22.00 & 23.78 & $108.07 \pm 0.59$ \\
& Phenolphthalein & 20.88 & 23.79 & $113.94 \pm 0.43$ \\
\hline \multirow{2}{*}{ High } & Caffeine & 33.00 & 34.65 & $105.00 \pm 0.64$ \\
& Phenolphthalein & 31.32 & 33.42 & $106.70 \pm 0.93$ \\
\hline
\end{tabular}

Table 4. Intra-day and inter-day precision of the HPLC method to detect and quantify caffeine and phenolphthalein, measured on three consecutive days

\begin{tabular}{llc}
\hline Day & Compound & \% RSD \\
\hline 1 & Caffeine & $0.68-1.14 \%$ \\
& Phenolphthalein & $0.84-1.55 \%$ \\
2 & Caffeine & $1.22-1.48 \%$ \\
& Phenolphthalein & $1.00-1.52 \%$ \\
3 & Caffeine & $1.41-1.85 \%$ \\
& Phenolphthalein & $0.93-1.79 \%$ \\
\hline
\end{tabular}

\section{Stability of mixed working standard solution}

Mixed working standard solution $(50 \mu \mathrm{g} / \mathrm{mL})$ was found to be stable over up to 24 hours under refrigeration conditions $\left(4{ }^{\circ} \mathrm{C}\right)$. Stability values for caffeine and phenolphthalein were $99.0 \pm 0.9 \%$ and $97.4 \pm 2.5 \%$, respectively. The stability values are summarised in Table 5 below.

Table 5. Stability of mixed working standard solution at $4^{\circ} \mathrm{C}$ after 24 hours

\begin{tabular}{llc}
\hline Solution & Compounds & Stability $(\%)(\mathbf{n}=\mathbf{3})$ \\
\hline Mixed working solution & Caffeine & $99.0 \pm 0.9$ \\
$(50 \mu \mathrm{g} / \mathrm{mL})$ & Phenolphthalein & $97.4 \pm 2.5$ \\
\hline
\end{tabular}

\section{Robustness}

System suitability parameters (precision, peak symmetry, number of theoretical plates, retention factor and resolution) remained within the acceptable limit range $[20,26,27]$ after deliberate changes in the three robustness parameters tested (Table 6). This indicates robustness of method for flow rate $\pm 0.2 \mathrm{~mL} / \mathrm{min}$, buffer $\mathrm{pH} \pm 0.2$ units and organic content $\pm 2.0 \%$.

\section{Analysis of representative samples}

Five herbal weight reducing supplements (products A, B, C, D and E) were purchased from the Kuala Lumpur area. All the products were advertised by the manufacturers to be derived from natural plant sources. The concentrations of caffeine and phenolphthalein quantified in the products are summarised in Table 7 below. Phenolphthalein was 


\section{Wong \& Nasr: DEVELOPMENT AND VALIDATION OF A REVERSE PHASE-HIGH PERFORMANCE LIQUID CHROMATOGRAPHY-ULTRAVIOLET METHOD FOR SIMULTANEOUS DETECTION OF CAFFEINE AND PHENOLPHTHALEIN IN WEIGHT REDUCING SUPPLEMENTS}

detected in two of the five products. Product A was found to contain the highest amount of phenolphthalein, about $40 \mathrm{mg}$ per capsule. The chromatogram of product A is shown in Figure 5 below. As the instruction on the product label recommends three capsules daily, a consumer may be ingesting up to $120 \mathrm{mg}$ of phenolphthalein a day. The typical dose for adults before it was withdrawn as a laxative was $30-200 \mathrm{mg}$, and it was not recommended to exceed $270 \mathrm{mg}$ [28]. Phenolphthalein has been detected as an undeclared drug in weight reducing supplements around the world in concentrations ranging from $48.20-1167 \mathrm{mg} / \mathrm{capsule}$ of $\mathrm{mg} / \mathrm{pill}[2,29]$ and $13.8-45.4 \mathrm{mg} / \mathrm{g}$ [5]. It is expected that adulteration of weight reducing products with phenolphthalein will be identified more frequently in the future, as phenolphthalein is widely available in laboratories and is cheap.

Table 6. System suitability parameters after deliberate changes in flow rate, buffer $\mathrm{pH}$ and buffer organic content of the mobile phase

\begin{tabular}{|c|c|c|c|c|c|c|c|}
\hline Parameter & & Compound & $\begin{array}{c}\text { Precision } \\
\text { (\% RSD) } \\
n=6\end{array}$ & $\begin{array}{c}\text { Peak } \\
\text { Symmetry }\end{array}$ & $\begin{array}{c}\text { Number of } \\
\text { Theoretical } \\
\text { Plates }\end{array}$ & $\begin{array}{c}\text { Retention } \\
\text { Factor }\end{array}$ & Resolution \\
\hline \multirow{4}{*}{$\begin{array}{l}\text { Flow rate, } \\
\mathrm{mL} / \mathrm{min}\end{array}$} & \multirow[t]{2}{*}{0.9} & Caffeine & 1.53 & 1.3 & 48771 & 2.59 & 25.35 \\
\hline & & Phenolphthalein & 1.39 & 1.2 & 53313 & 4.66 & \\
\hline & \multirow[t]{2}{*}{1.3} & Caffeine & 2.80 & 1.4 & 41145 & 1.89 & 25.89 \\
\hline & & Phenolphthalein & 2.54 & 1.2 & 57037 & 3.64 & \\
\hline \multirow[t]{4}{*}{ Buffer $\mathrm{pH}$} & \multirow[t]{2}{*}{4.8} & Caffeine & 4.10 & 1.3 & 18719 & 2.19 & 21.08 \\
\hline & & Phenolphthalein & 2.52 & 1.4 & 57110 & 4.07 & \\
\hline & \multirow[t]{2}{*}{5.2} & Caffeine & 3.83 & 1.2 & 22693 & 2.19 & 22.28 \\
\hline & & Phenolphthalein & 4.08 & 1.2 & 58254 & 4.07 & \\
\hline \multirow{4}{*}{$\begin{array}{l}\text { Organic } \\
\text { Content }\end{array}$} & \multirow[t]{2}{*}{$+2 \%$} & Caffeine & 2.57 & 1.8 & 15374 & 2.10 & 19.91 \\
\hline & & Phenolphthalein & 3.53 & 1.3 & 76249 & 4.84 & \\
\hline & \multirow[t]{2}{*}{$-2 \%$} & Caffeine & 3.58 & 1.5 & 17140 & 2.28 & 21.99 \\
\hline & & Phenolphthalein & 0.01 & 1.4 & 49863 & 4.45 & \\
\hline
\end{tabular}

Table 7. Amount of caffeine and phenolphthalein measured in weight reducing supplements purchased from Kuala Lumpur

\begin{tabular}{lllcc}
\hline Product & Formulation & \multicolumn{3}{c}{ Analysis of Weight Reducing Supplements } \\
\cline { 3 - 5 } & & Analyte & Concentration $(\mathbf{m g} / \mathbf{g})$ & $\begin{array}{c}\text { Amount Consumed } \\
\text { per Sachet/Capsule (mg) }\end{array}$ \\
\hline A & Capsule & Caffeine & $1.51 \pm 0.038$ & $0.49 \pm 0.012$ \\
& & Phenolphthalein & $126.82 \pm 0.46$ & $40.73 \pm 0.14$ \\
B & Capsule & Caffeine & ND & ND \\
& & Phenolphthalein & $0.76 \pm 0.002$ & $0.63 \pm 0.002$ \\
C & Capsule & Caffeine & ND & ND \\
& & Phenolphthalein & ND & ND \\
D & Capsule & Caffeine & ND & ND \\
& & Phenolphthalein & ND & ND \\
E & Powder & Caffeine & $2.16 \pm 0.12$ & $43.28 \pm 2.48$ \\
& & Phenolphthalein & ND & ND \\
\hline
\end{tabular}

ND: Not detected 


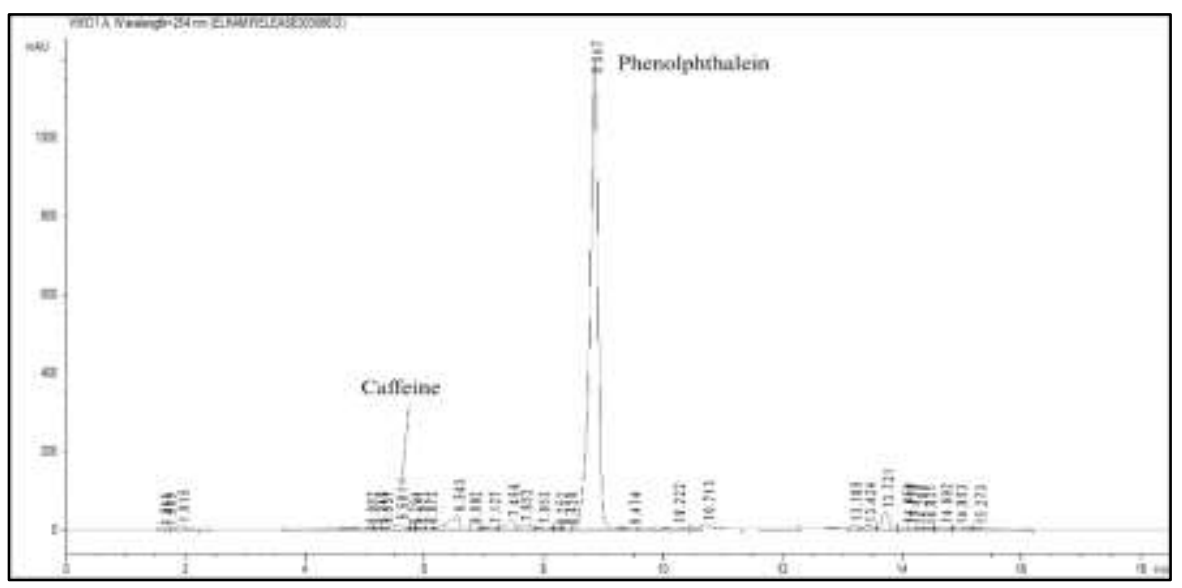

Figure 5. HPLC chromatogram of Product A. Caffeine and phenolphthalein elutes out at 5.581 and 8.847 minutes, respectively

Caffeine is classified by the FDA as generally recognised as safe (GRAS), with a toxic dose being over $10 \mathrm{~g}$ for an average adult. Caffeine was detected in two of the products, and the concentration measured to be within the safe limit. Further clean-up of product E was attempted by the LLE method to improve the reliability of caffeine measurement due to the complicated matrix in the product (Figure 6). The extraction method is as described in the materials and methods section. Product $\mathrm{E}$ was dissolved in basic solution prior to extraction of caffeine with dichloromethane. Water soluble impurities and tannins (if present) remained in the basic solution. As observed from the chromatogram in Figure 7, LLE may be an effective clean-up method for products with complicated matrices. However, it should be noted that products suspected to be adulterated with phenolphthalein should be dissolved in water instead of basic solution, as phenolphthalein contains acidic phenolic groups.

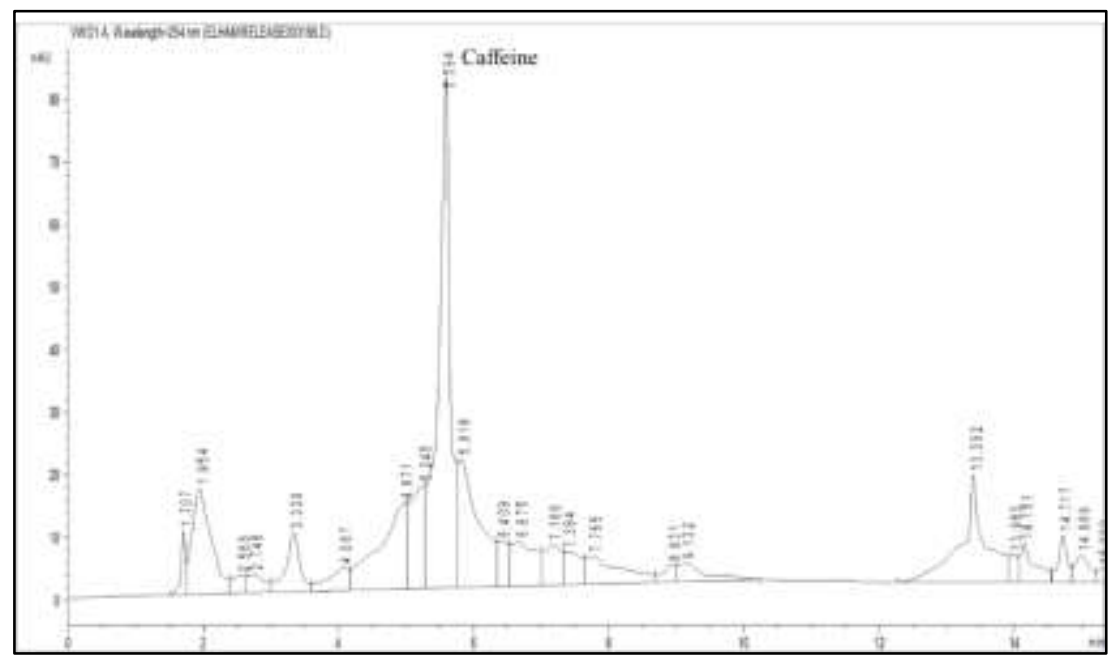

Figure 6. HPLC chromatogram of Product E before LLE. Caffeine elutes out at 5.594 minutes 


\section{Wong \& Nasr: DEVELOPMENT AND VALIDATION OF A REVERSE PHASE-HIGH PERFORMANCE LIQUID CHROMATOGRAPHY-ULTRAVIOLET METHOD FOR SIMULTANEOUS DETECTION OF CAFFEINE AND PHENOLPHTHALEIN IN WEIGHT REDUCING SUPPLEMENTS}

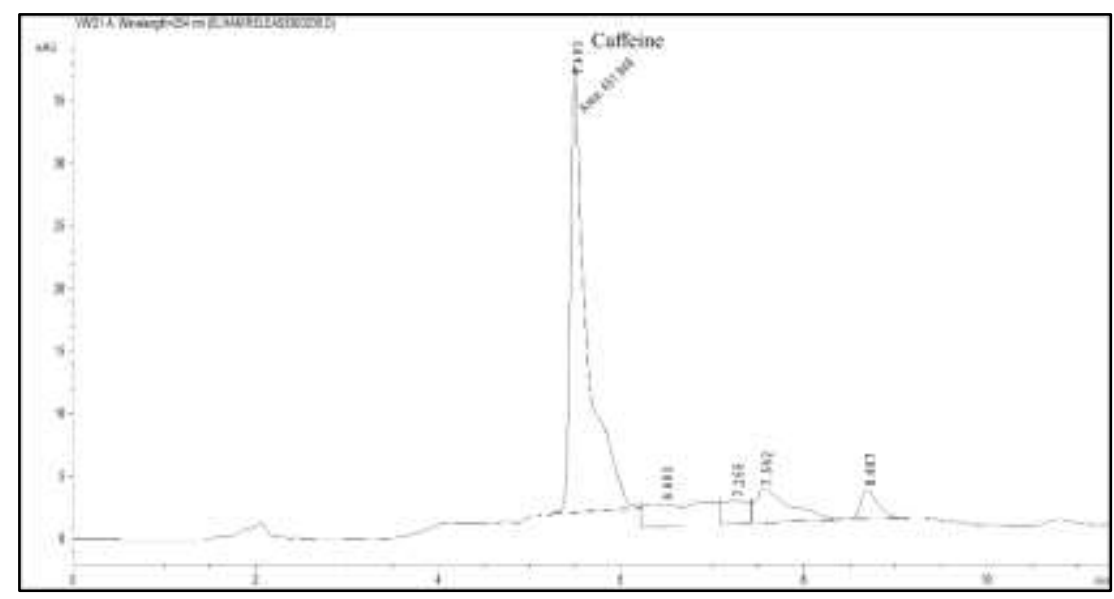

Figure 7. HPLC chromatogram of Product E after LLE. Caffeine elutes out at 5.493 minutes

\section{Conclusion}

A RP-HPLC-UV analytical method with variable wavelength detection was developed and validated for the simultaneous detection of caffeine and phenolphthalein in weight reducing supplements. Out of five supplements screened, two products were found to be adulterated with phenolphthalein. The validation was performed according to ICH guidelines. The HPLC method developed is selective, accurate, precise, robust and relatively fast (10 minutes). Moreover, the use of ammonium acetate buffer combined with methanol allows the transfer to a mass spectrometer, leading to a more thorough investigation in case of any doubt. The method can be easily adapted for rapid detection of caffeine and phenolphthalein in herbal products in quality control laboratories with a HPLC instrument.

\section{Acknowledgement}

This work was supported by the International Medical University (Project ID No.: MAPC I1/2013 (4)). The authors would like to thank Dr. Ng Sook Han for her assistance in supervising Ms Elham Mohammadi Nasr.

\section{References}

1. Arroyo-Johnson, C and Mincey, K. D. (2016). Obesity epidemiology worldwide. Gastroenterology Clinics, 45(4): $571-579$.

2. Ancuceanu, R., Dinu, M. and Arama, C. (2013). Weight loss food supplements: Adulteration and multiple quality issues in two products of chinese origin. Farmacia, 61(1): $28-44$.

3. de Carvalho, L. M., Martini, M., Moreira, A. P., de Lima, A. P., Correia, D., Falcão, T., Garcia, S. C., de Bairros, A. V., do Nascimento, P. C. and Bohrer, D. (2011). Presence of synthetic pharmaceuticals as adulterants in slimming phytotherapeutic formulations and their analytical determination. Forensic Science International, 204(1-3): 6-12.

4. Ioset, J. R., Raoelison, G. E. and Hostettmann, K. (2003). Detection of aristolochic acid in chinese phytomedicines and dietary supplements used as slimming regimens. Food and Chemical Toxicology, 41(1): $29-36$.

5. Wang, J., Chen, B. and Yao, S. (2008). Analysis of six synthetic adulterants in herbal weight-reducing dietary supplements by LC electrospray ionization-MS. Food Additives \& Contaminants. Part A, Chemistry, Analysis, Control, Exposure \& Risk Assessment, 25(7): 822 - 830.

6. Shi, Y., Sun, C., Gao, B. and Sun, A. (2011). Development of a liquid chromatography tandem mass spectrometry method for simultaneous determination of eight adulterants in slimming functional foods. Journal of Chromatography A, 1218(42): 7655 - 7662.

7. Haneef, J., Shaharyar, M., Husain, A., Rashid, M., Mishra, R., Siddique, N. A. and Pal, M. (2013). Analytical methods for the detection of undeclared synthetic drugs in traditional herbal medicines as adulterants. Drug Testing and Analysis, 5(8): 607 - 613. 
8. Dunn, J. D., Gryniewicz-Ruzicka, C. M., Mans, D. J., Mecker-Pogue, L. C., Kauffman, J. F., Westenberger, B. J. and Buhse, L. F. (2012). Qualitative screening for adulterants in weight-loss supplements by ion mobility spectrometry. Journal of Pharmaceutical and Biomedical Analysis, 71: 18 - 26.

9. Rebiere, H., Guinot, P., Civade, C., Bonnet, P. and Nicolas, A. (2012). Detection of hazardous weight-loss substances in adulterated slimming formulations using ultra-high-pressure liquid chromatography with diodearray detection. Food Additives \& Contaminants. Part A, Chemistry, Analysis, Control, Exposure \& Risk Assessment, 29(2): $161-171$.

10. Deconinck, E., Verlinde, K., Courselle, P. and Beer J. O. (2012). A validated ultra high pressure liquid chromatographic method for the characterisation of confiscated illegal slimming products containing anorexics. Journal of Pharmaceutical and Biomedical Analysis, 59: 38 - 43.

11. Phattanawasin, P., Sotanaphun, U., Sukwattanasinit, T., Akkarawaranthorn, J. and Kitchaiya, S. (2012). Quantitative determination of sibutramine in adulterated herbal slimming formulations by TLC-image analysis method. Forensic Science International, 219: 96 - 100.

12. Food and Drug Administration. Drugs (2009). Available from: http://www.fda.gov/Drugs/ResourcesForYou/ Consumers/QuestionsAnswers/ucm136187.htm. Date acces on 1 April 2017.

13. Dunnick, J. K. and Hailey, J. R. (1996). Phenolphthalein exposure causes multiple carcinogenic effects in experimental model systems. Cancer Research, 56(21): 4922 - 4926.

14. World Health Organization (1998). World drug information. Essential Medicines and Pharmaceutical Policies, 12(1): $1-21$.

15. International Agency on Research for Cancer (2000). Some antiviral and antineoplastic drugs, and other pharmaceutical agents. IARC Monographs on the Evaluation of Carcinogenic Risks to Humans, 76: 387 - 415.

16. Barone, J. J. and Roberts, H. (1984). Human consumption of caffeine. Caffeine, 59 - 73.

17. Diepvens, K., Westerterp, K. R. and Westerterp-Plantenga, M. S. (2007). Obesity and thermogenesis related to the consumption of caffeine, ephedrine, capsaicin, and green tea. American Journal of Physiology - Regulatory, Integrative and Comparative Physiology, 292(1): 77 - 85.

18. Snel, J. and Lorist, M. M. (2011). Effects of caffeine on sleep and cognition. Progress in Brain Research, 190: $105-117$.

19. Cannon, M. E., Cook, C. T. and McCarthy, J. S. (2001). Caffeine-induced cardiac arrhythmia: An unrecognised danger of healthfood products. Medical Journal of Australia, 174(10): 520 - 521.

20. International Conference on Harmonisation (1996). Guidance for industry Q2B validation of analytical procedures: Methodology: pp. $1-10$.

21. Zheng-Fei, P. (2011). Determination of caffeine, phenolphthalein and sibutramine illegally added to weight loss functional food with UPLC/MS/MS. China Tropical Medicine, 11(9): 1116 - 1117.

22. Hammadi, R. and Almardini, M. A. (2014). A fully validated HPLC-UV method for quantitative and qualitative determination of six adulterant drugs in natural slimming dietary supplements. International Journal of Pharmaceutical Sciences Review and Research, 29(1): 171 - 174.

23. National Center for Biotechnology Information (2004). Caffeine. Available from: http://pubchem.ncbi. nlm.nih.gov/summary/summary.cgi?cid=2519. Acesss online on 1 April 2017.

24. National Center for Biotechnology Information (2005). Phenolphthalein. Available from: http://pubchem.ncbi. nlm.nih.gov/summary/summary.cgi?cid=4764. Access online on 1 April 2017.

25. Rahim, A. A., Nofrizal, S. and Saad, B. (2014). Rapid tea catechins and caffeine determination by HPLC using microwave-assisted extraction and silica monolithic column. Food Chemistry, 147: 262 - 288.

26. Shabir, G. (2003). Validation of high-performance liquid chromatography methods for pharmaceutical analysis. understanding the differences and similarities between validation requirements of the US Food and Drug Administration, the US Pharmacopeia and the International Conference on Harmonization. Journal of Chromatography A, 987(1-2): 56 - 66.

27. Center for Drug Evaluation and Research CDER (1994). Reviewer guidance-validation of chromatographic methods: pp. $1-30$.

28. U.S. Department of Health and Human Services. (2016). 14th Report on carcinogens (phenolphthalein). National Toxicology Program. 
Wong \& Nasr: DEVELOPMENT AND VALIDATION OF A REVERSE PHASE-HIGH PERFORMANCE LIQUID CHROMATOGRAPHY-ULTRAVIOLET METHOD FOR SIMULTANEOUS DETECTION OF CAFFEINE AND PHENOLPHTHALEIN IN WEIGHT REDUCING SUPPLEMENTS

29. Khazan, M., Hedayati, M., Kobarfard, F., Askari, S. and Azizi, F. (2014). Identification and determination of synthetic pharmaceuticals as adulterants in eight common herbal weight loss supplements. Iranian Red Crescent Medical Journal, 16(3): 15344 - 15350. 